\title{
Clinical and Demograhical Characteristics of Patients with Maxillofacial Trauma in the Emergency Department
}

\author{
Seval Komut¹, Bedriye Müge Sönmez ${ }^{1}$, Ali Kemal Erenler ${ }^{2 *}$, Erdal Komut ${ }^{3}$ \\ ${ }^{1}$ Department of Emergency Medicine, Ankara Numune Education and Research Hospital, Ankara, Turkey \\ ${ }^{2}$ Department of Emergency Medicine, Hitit University, School of Medicine, Çorum, Turkey \\ ${ }^{3}$ Department of Radiodiagnostics, Hitit University, School of Medicine, Çorum, Turkey \\ Email: *akerenler@hotmail.com
}

How to cite this paper: Komut, S., Sönmez, B.M., Erenler, A.K. and Komut, E. (2019) Clinical and Demograhical Characteristics of Patients with Maxillofacial Trauma in the Emergency Department. Open Journal of Emergency Medicine, 7, 28-39.

https://doi.org/10.4236/ojem.2019.72004

Received: October 20, 2019

Accepted: June 7, 2019

Published: June 10, 2019

Copyright $\odot 2019$ by author(s) and Scientific Research Publishing Inc. This work is licensed under the Creative Commons Attribution International License (CC BY 4.0).

http://creativecommons.org/licenses/by/4.0/

\begin{abstract}
Objective: We aimed to investigate the clinical and demographical characteristics of patients admitted to the Emergency Department (ED) due to maxillofacial trauma (MFT). Methods: This sectional and retrospective study was conducted in Ankara Numune Education and Research Hospital ED between 1st March 2010 and 31st March 2017. Into the study, patients with MFT older than 15 years of age were included. Characteristics of patients were recorded. Patients' characteristics were compared according to presence of fractures. Results: Mean age of the patients was $41.1 \pm 18.0$ years and a statistically significant relationship was determined between age and presence of fracture ( $\mathrm{p}>0.05)$. Of the patients, $74.5 \%$ was male and fracture presence was significantly more in males than females $(\mathrm{p}<0.05)$. The most common reason for MFT was assaults (36.5\%) followed by motor vehicle accidents $(29.1 \%)$ and fall from height (26.9\%). Of the patients, $48.7 \%$ had soft tissue injury, $31.4 \%$ had maxilla fracture, $23.8 \%$ had nasal fracture. Also, blow-out fracture in $6.6 \%$, Le Fort in $4.2 \%$ and blow-in in $0.3 \%$ were determined. $36 \%$ of the patients were hospitalized and the most common wards were plastic surgery (32\%) and neurosurgery (23.5\%). The mortality rate in our study was found to be $1.6 \%$ and there was not a relationship between the presence of MFT and mortality ( $p>0.05$ ). Conclusion: The MFT is a pathology that either leads to its own, or can lead to life-threatening consequences as a result of additional organ injuries. The physician evaluating the patient should determine the MFT and additional pathologies and ensure that the interventions start as soon as possible.
\end{abstract}

\section{Keywords}

Maxillofacial Trauma, Emergency Department, Maxillofacial Fracture 


\section{Introduction}

Trauma is the leading cause of death in individuals under 40 years [1] [2]. Maxillofacial trauma (MFT) is one of the most common traumas applying to the Emergency Department (ED). The trauma may either be isolated or accompany other system injuries [2] [3]. Face is an essential body part of appearance and functioning. Facial traumas may affect some vital functions (eating, drinking, communication with other people, etc). Studies revealed that injuries with disfiguration may cause severe social and psychological problems [4]. MFTs account for a large proportion of emergency department visits and often result in surgical consultation. The management of MFTs mainly focuses not only on eliminating life-threatening conditions but also maintaining functionality and cosmetic appearance. Management of such traumas improves as diagnostic technology and treatment methods develop. The objective of trauma imaging is to determine number, location and severity of the injuries. So that functionality may be maintained, probable complications may be reduced and cosmetic problems may be avoided. Although many of the principles of detection and repair are basic, the evolution of technology and therapeutic strategies has led to improved outcomes of patients [5] [6]. X-ray imaging is inadequate to expose trauma severity and amount of displacement. Multi-slice computerized tomography (CT) is the most preferred imaging method.

In this study, we aimed to investigate the demographical characteristics of patients with MFT. We also aimed to analyse accompanying injuries to MFTs.

\section{Materials and Method}

This study was conducted in Ankara Numune Education and Research Hospital between 1st March 2010 and 31st March 2017, retrospectively. Ethical approval was obtained from Local Ethics Committee.

Ankara Numune Education and Research Hospital serves to 200,000 patients annually and is located in the capital city of Turkey, Ankara.

It admits patients older than 18 years and annual number of trauma patients is about 50,000. Our study group consisted of patients older than 15 years with MFT requiring CT imaging. Exclusion criteria were patients younger than 15 years, patients died before arrival to the ED and patients of whom the medical records could not be obtained.

Age, gender, reason for trauma, accompanying system injuries, and hospitalization status and mortality rates of the patients were recorded. A fracture presence was considered as an indicator of trauma severity. CT imagings of the patients were evaluated by radiology specialists of the Hospital. Patients' characteristics were compared according to fracture presence.

\section{Statistical Analyses}

For statistical analyses, Statistical Package for Social Sciences (SPSS) 19.0 program was used. Descriptive statistics were performed using Kolmogorov-Smirnov test. While quantitative data were given as mean and standard deviation (SD), qualit- 
ative data were given as numbers (n) and percentages (\%). Quantitative parametric data analysis was performed using Student T-test. In comparison of two qualitative variables, Chi-Square test was used. Results were given in a confidential interval of $95 \%$ and $p<0.05$ was considered as statistically significant.

\section{Results}

Of 910 patients involved into the study, the mean age was $41.1 \pm 18.0$ (min: 15, max: 113 years). 678 of the patients (74.5\%) were male and $232(25.5 \%)$ were female.

While the mean age of the patients with a fracture due to MFT was $41.1 \pm 17.2$ years, the mean age of the patients without a fracture was $41.1 \pm 18.9$ years. Any statistical significance could not be obtained between age and fracture presence ( $p>0.05)$. In 376 of male patients (80.5\%) and in 91 of female patients (19.5\%), a fracture has been determined. In 302 of male patients (68.2\%) and in 141 of female patients $(31.8 \%)$ any fractures could not be determined. Fracture presence was more common in male patients $(\mathrm{p}<0.05)$. When reasons for MFT was investigated, assault was the most common reason (314, 34.5\%), followed by motor vehicle accident $(265,29.1 \%)$, crash $(45,4.9 \%)$, fire-arm related injury (30, $3.3 \%)$, stab injuries $(6,0.7 \%)$, and other causes $(5,0.5 \%)$. Fracture presence in motor vehicle accidents was statistically higher $(\mathrm{p}<0.05)$. See Table 1 for details.

In 443 of the patients (48.7\%) any fracture could not be determined. A fracture was determined in 286 (31.4\%) in maxilla, in 230 (25.3\%) in nasal bone, in $217(23.8 \%)$ in orbita, in $144(15.8 \%)$ in zygoma, in $125(13.7 \%)$ in mandibula and in $83(9.1 \%)$ in frontal bone (Table 2). In addition, a blow-out fracture was determined in $60(6.6 \%)$ and a blow-in fracture was determined in $3(0.3 \%)$. In 47 of the patients $(5.2 \%)$, a complex fracture involving zygomaticomaxillar bones was determined. While 9 patients (1\%) had Le fort Type I fracture, 10 (1.1\%) had Le Fort Type II and 19 (2.1\%) had Le Fort Type III fracture. In 34 of the patients (3.7\%), nasoorbitoethmoid-type fracture was observed (Table 3).

An additional head trauma was determined in 112 patients (12.3\%). Accompanying intracerebral injuries were as follows: subarachnid bleeding in 48 (5.3\%), contusio cerebri in $27(3 \%)$, subdural hematoma in $22(2.4 \%)$, epidural hemorrhage in $20(2.2 \%)$, pneumocephaly in $18(2 \%)$, calvarial hematoma in 15 (1.6\%) and diffuse axonal injury in $7(0.8 \%)$. In patients with fracture presence following MFT, prevalence of subarachnoid bleeding was significantly higher ( $\mathrm{p}$ $<0.05)$. Any relationship between other intracerebral injuries and fracture presence following MFT could not be obtained ( $p>0.05$ ).

In our study, a spinal injury was observed in 30 patients (3.3\%). Accompanying spinal injuries were as follows: cervical vertebra fracture in $18(2 \%)$, thoracal vertebra fracture in $12(1.3 \%)$, and lumber vertebra fracture in $3(0.3 \%)$. Any relationship between presence of fracture following MFT and spinal injuries could not be determined $(\mathrm{p}>0.05)$.

In 59 patients (6.5\%), an accompanying intrathoracal injury was determined. 
Table 1. Comparison of patient characteristics according to fracture presence.

\begin{tabular}{|c|c|c|c|}
\hline & Fracture (+) & Fracture (-) & $\mathrm{p}$ \\
\hline Age $n$, Mean \pm SD & $467,41.1 \pm 17.2$ & $443,41.1 \pm 18.9$ & 0.999 \\
\hline \multicolumn{4}{|l|}{ Gender (n, \%) } \\
\hline Male & $376(\% 80.5)$ & $302(\% 68.2)$ & \multirow{2}{*}{$<0.001$} \\
\hline Female & $91(\%$ 19.5) & $141(\% 31.8)$ & \\
\hline \multicolumn{4}{|l|}{ Mechanism of Trauma (n, \%) } \\
\hline Assault & $151(32.3)$ & $163(36.8)$ & \\
\hline Motor Vehicle & $157(33.6)$ & $108(24.4)$ & \\
\hline Fall & $112(24)$ & $133(30)$ & \\
\hline Crash & $25(5.4)$ & $20(4.5)$ & 0.012 \\
\hline Fire Arm & $17(3.6)$ & $13(2.9)$ & \\
\hline Stabbing & $1(0.2)$ & $5(1.1)$ & \\
\hline Others & $4(0.9)$ & $1(0.2)$ & \\
\hline \multicolumn{4}{|c|}{ Accompanying Head Trauma (n, \%) } \\
\hline Multiple Injuries & $76(16.3)$ & $36(8.1)$ & $<0.001$ \\
\hline Subarachnoid Hemorrhage & $32(6.9)$ & $16(3.6)$ & 0.029 \\
\hline Contusio Cerebri & $18(3.9)$ & $9(2)$ & 0.105 \\
\hline Subdural Hemorrhage & $14(3)$ & $8(1.8)$ & 0.242 \\
\hline Epidural Hemorrhage & $13(2.8)$ & $7(1.6)$ & 0.216 \\
\hline Pneumocephaly & $12(2.6)$ & $6(1.4)$ & 0.188 \\
\hline Calvarial Hematoma & $4(0.9)$ & $11(2.5)$ & 0.054 \\
\hline \multicolumn{4}{|l|}{ Diffuse Axonal Injury } \\
\hline \multicolumn{4}{|c|}{ Accompanying Spinal Trauma (n, \%) } \\
\hline Multiple Injuries & $16(3.4)$ & $14(3.2)$ & 0.822 \\
\hline Cervical Vertebrae & $11(2.4)$ & $7(1.6)$ & 0.401 \\
\hline Thoracal Vertebrae & $5(1.1)$ & $7(1.6)$ & 0.501 \\
\hline Lomber Vertebrae & $1(0.2)$ & $2(0.5)$ & 0.615 \\
\hline \multicolumn{4}{|c|}{ Accompanying Thorax Trauma (n, \%) } \\
\hline Multiple Injuries & $35(7.5)$ & $24(5.4)$ & 0.203 \\
\hline Costa Fracture & $22(4.7)$ & $10(2.3)$ & 0.055 \\
\hline Lung Contusion & $16(3.4)$ & $14(3.2)$ & 0.822 \\
\hline Pneumothorax/Hemothorax & $5(1.1)$ & $7(1.6)$ & 0.501 \\
\hline \multicolumn{4}{|c|}{ Accompanying Abdominal Trauma (n, \%) } \\
\hline Multiple Injuries & $24(5.1)$ & $15(3.4)$ & 0.192 \\
\hline Pelvis Fracture & $14(3)$ & $12(2.7)$ & 0.794 \\
\hline Splenic Injury & $5(1.1)$ & $3(0.7)$ & 0.726 \\
\hline Liver Injury & $3(0.6)$ & $1(0.2)$ & 0.625 \\
\hline
\end{tabular}




\section{Continued}

\begin{tabular}{|c|c|c|c|}
\hline Bowel Perforation & $2(0.4)$ & $1(0.2)$ & $>0.999$ \\
\hline Pelvic hematoma & $1(0.2)$ & $1(0.2)$ & $>0.999$ \\
\hline Retroperitoneal Hematoma & $0(0)$ & $2(0.5)$ & 0.237 \\
\hline \multicolumn{4}{|c|}{ Accompanying Extremity Trauma (n, \%) } \\
\hline Upper Extremity & $41(8.8)$ & $23(5.2)$ & 0.054 \\
\hline Lower Extremity & $29(6.2)$ & $18(4.1)$ & 0.144 \\
\hline \multicolumn{4}{|l|}{ Alcohol Intake } \\
\hline Yes & $100(21.4)$ & $85(19.2)$ & \multirow{2}{*}{0.404} \\
\hline No & $367(78.6)$ & $358(80.8)$ & \\
\hline \multicolumn{4}{|l|}{ Hospitalization } \\
\hline Yes & $223(47.8)$ & $105(23.7)$ & \multirow{2}{*}{$<0.001$} \\
\hline No & $244(52.2)$ & $338(76.3)$ & \\
\hline \multicolumn{4}{|l|}{ Ward } \\
\hline Plastic Surgery & $91(40.8)$ & $16(15.2)$ & \multirow{10}{*}{$<0.001$} \\
\hline Neurosurgery & $54(24.2)$ & $23(21.9)$ & \\
\hline Orthopedics & $30(13.5)$ & $19(18.1)$ & \\
\hline Intensive Care Unit & $21(9.4)$ & $16(15.2)$ & \\
\hline Ophtalmology & $12(5.4)$ & $19(18.1)$ & \\
\hline Thorax Surgery & $8(3.6)$ & $5(4.8)$ & \\
\hline General Surgery & $6(2.7)$ & $1(1)$ & \\
\hline Ear-Nose-Throat & $1(0.4)$ & $3(2.9)$ & \\
\hline Neurology & $0(0)$ & $2(1,9)$ & \\
\hline Burn Unit & $0(0)$ & $1(1)$ & \\
\hline \multicolumn{4}{|l|}{ Outcome } \\
\hline Exitus & $11(2.4)$ & $4(0.9)$ & \multirow{2}{*}{0.085} \\
\hline Survivors & $456(97.6)$ & $439(99.1)$ & \\
\hline
\end{tabular}

They were as follows: costa fracture in 32 (3.5\%), contusion in 30 (3.3\%), pneumohemothorax in $12(1.3 \%)$. There was not a relationship between fracture presence following MFT and intrathoracic injuries ( $\mathrm{p}>0.05)$.

In 39 patients (4.3\%), there was an accompanying abdominopelvic injury. They were as follows: pelvic fracture in $26(2.9 \%)$, splenic injury in 8 (0.9\%), hepatic injury in $4(0.4 \%)$, bowel perforation in $3(0.3 \%)$, pelvic hematoma in $2(0.2 \%)$ and retroperitoneal hematoma in $2(0.2 \%)$. There was not a statistical relationship between fracture presence following MFT and abdominopelvic injuries ( $p>0.05)$.

In addition, while an upper extremity injury was determined in 64 patients (7\%), a lower extremity injury was determined in 47 patients (5.2\%). There was not a relationship between fracture presence following MFT and extremity injuries $(\mathrm{p}>0.05)$. 
Table 2. Localization of fracture.

\begin{tabular}{|c|c|c|c|}
\hline & & Subgroup n (\%) & Total n (\%) \\
\hline Soft Tissue Injury & & & $443(48.7)$ \\
\hline Maxilla Fracture & & & $286(31.4)$ \\
\hline \multirow[t]{3}{*}{ Nasal Fracture } & Nasal Bone & $217(23.8)$ & \\
\hline & Nasal Septum & $4(0.4)$ & $230(25.3)$ \\
\hline & Both & $9(1.0)$ & \\
\hline Orbita Fracture & & & $217(23.8)$ \\
\hline \multirow[t]{2}{*}{ Zygoma Fracture } & Zygomatic Arch & $121(13.3)$ & \\
\hline & Others & $23(2.5)$ & $144(15.0)$ \\
\hline \multirow[t]{6}{*}{ Mandible Fracture } & Corpus & $48(5.3)$ & \\
\hline & Ramus & $28(3.1)$ & \\
\hline & Condyle & $15(1.6)$ & \\
\hline & Parasymphisis & $7(0.8)$ & $125(13.7)$ \\
\hline & Symphisis & $2(0.2)$ & \\
\hline & Combined & $25(2.7)$ & \\
\hline Frontal Fracture & & & $83(9.1)$ \\
\hline \multirow[t]{7}{*}{ Others } & Sphenoid & $94(10.3)$ & \\
\hline & Parietal & $55(6)$ & \\
\hline & Temporal & $47(5.2)$ & \\
\hline & Occipital & $8(0.9)$ & $148(16.2)$ \\
\hline & Ethmoid & $2(0.2)$ & \\
\hline & Lacrimal & $2(0.2)$ & \\
\hline & Lamina Papricea & $1(0.1)$ & \\
\hline
\end{tabular}

Table 3. Distribution of blow out/in and le fort fractures.

\begin{tabular}{lcc}
\hline & & $\mathrm{n}(\%)$ \\
\hline Blow Out/In & Blow out & $60(6.6)$ \\
Zygomaticomaxillar Complex & Blow in & $3(0.3)$ \\
Le Fort & & $47(5.2)$ \\
& Type I & $9(1)$ \\
& Type II & $10(1.1)$ \\
Nasoorbitoethmoid Fractures & Type III & $19(2.1)$ \\
\hline
\end{tabular}

Alcohol intake was determined in 185 patients (20.3\%). Alcohol intake was not related to fracture presence following MFT ( $p>0.05)$.

Of the patients involved into our study, 328 (36\%) were hospitalized. Of the patients with a fracture, $223(47.8 \%)$ were hospitalized and 224 (52.2\%) were 
discharged from ED. Of the patients without a fracture, 105 (21.9\%) were hospitalized and $338(76.3 \%)$ were discharged from ED. Presence of a fracture was significantly related with hospitalization $(\mathrm{p}<0.05)$.

In our study, of the patients, 107 (32.6\%) were hospitalized in plastic surgery, 77 (23.5\%) were hospitalized in neurosurgery, 49 (14.9\%) were hospitalized in orthopedics, $37(11.3 \%)$ was hospitalized in intensive care unit, 31 (9.5\%) were hospitalized in otology, 13 (4\%) were hospitalized in thorax surgery, 7 (2.1\%) were hospitalized in general surgery, $4(1.2 \%)$ was hospitalized in ear-nose-throat, 2 (0.6\%) were hospitalized in neurology and $1(0.3 \%)$ was hospitalized in burn unit wards. While patients with a fracture were significantly hospitalized in plastic surgery and neurosurgery wards, patients without a fracture were significantly hospitalized in neurosurgery, orthopedics, otology and intensive care unit $(\mathrm{p}<$ 0.05).

In-hospital mortality was determined to be $1.6 \%$ (15 patients). Among patients with a fracture, mortality rate was $2.4 \%$ (11 patients). At the other hand, 4 of the patients without a fracture have died (0.9\%). Any relationship could not be obtained between fracture presence and mortality $(\mathrm{p}>0.05)$.

\section{Discussion}

Face is the most important region in human body from esthetic aspect. So, diagnosis and treatment of facial fracture are important for social and psychological reasons [7]. Commonly, MFT is a field of plastic surgeons and consists of a significant portion of traumas. Etiology is commonly motor vehicle accidents, falls from height, assaults, occupational and sports injuries and varies according to age, gender, region and social status [8].

In the literature, there are numerous studies investigating patients with facial fractures. In majority of these studies, fracture types have been compared. In our study, an additional analysis of patients with and without a fracture has been performed. In the literature, majority of the patients with MFT is in the young age group [9]-[16]. However in our study, mean age was $41.1 \pm 18.0$ years and age was not related to fracture presence. Fracture presence may be related to severity of the trauma rather than age. Geriatric patients tend to fall frequently and have fractures due to co-morbidities such as osteoporosis leading to bone fragility. On the other hand, young individuals take part in social life more often may expose to assaults and motor vehicle accidents frequently.

In a study, it was reported that male patients expose to MFT ninefold more than females [10]. In our study, accordingly, $74.5 \%$ of the patients with fracture were males. This result was in concordance with the literature [8] [11]-[16]. Male patients frequently participate in hard works and drive vehicles. Thus, they expose to traffic accidents, occupational injuries, assaults and fire-arm/stab injuries. Also, male individuals tend to use fists and hard objects in fights and expose to MFT and facial fractures more often.

Etiology of MFT vary from region to region. Motor vehicle accidents are the 
major reason for MFT in under-developed and developing countries, assaults are the main reason in developed countries [1]. Insufficient traffic understructure and disobey to traffic rules in under-developed countries may be the reason for this result [17] [18]. Nevertheless, the traffic accident is the most common reason for MFTs followed by assaults [19] [20]. There are also reports in the literature revealing that assault is the major cause of fracture due to MFTs [21] [22].

In our study, the most common reason for MFTs was assaults followed by motor vehicle accidents and falls. Motor vehicle accidents and assaults are well-described in the literature as the leading causes of MFTs [8] [11] [12] [13] [14] [15] [22] [23]. Numerous factors such as car security systems, socio-cultural status of the community, traffic road conditions and violence frequency in the community affect the reasons for MFTs. Seat belt use among drivers and helmet use among motorcyclists may also prevent MFTs.

It is known that mandible fractures most commonly occur in condyle followed by corpus and angulus [10] [12] [24]. When maxilla fracture is classified, the most common type is Le Fort III (75\%), followed by Le Fort II (17.4) and Le Fort I (8.3\%) [12]. In a study from Turkey, 37 patients with MFT were divided into two groups as isolated and combined MFTs. In the isolated group, the most common fracture sites were mandible (81.09\%), maxilla (8.11\%), zygoma (2.7\%). In the combined group, the most common fracture sites were maxilla and mandible (5.4\%) and zygoma and maxilla (2.7\%) [13]. In another study with 232 patients, it was reported that isolated fracture was determined in $78.5 \%$ of the patients. In 21.5\%, combined fractures were determined. Mandible was the most common fractured region followed by maxilla, zygoma, orbita and naso-orbito-ethmoid regions [8]. Ylldirım et al. retrospectively analysed the CT results of patients with MFT. Of 420 patients, $42.8 \%$ had a fracture on orbita or maxillofacial structures [25]. In another study, $43 \%$ of the 121 patients with MFT had mandible fracture and $30 \%$ had zygoma fracture. Of those with maxilla fracture, $43 \%$ had Le Fort I, $28 \%$ had Le Fort II and 16\% had Lefort III fractures [15]. In our study, fractures were generally observed in maxilla (corpus) (31.4\%), followed by nasal (23.8\%), orbital (23.8\%), zygoma (arcus) (15.8\%), and mandible (14.5\%). In $6.6 \%$ of the patients, blow-out fracture was observed. In $4.2 \%$, Le Fort (type III most commonly) and in $0.3 \%$, blow-in fracture was determined. Since the most common reason for MFT in our study was assaults, frontal punches and strikes may cause maxilla fractures. Relatively rigid structure of mandible may prevent it from fractures when compared to maxillar structures. The reason for the higher prevalence of Le Fort type III fractures may be admittance of complicated trauma patients to our hospital which serves as a trauma center of the region.

It was previously reported in the US and Puerto Rico that MFTs commonly accompany with cervical vertebrae fractures $(4.9 \%-8 \%)$, and head traumas $(28.7 \%-79.9 \%)$ [26]. In females, orthopedic traumas were commonly found to accompany MFTs (23.2\%), followed by head and spinal traumas [27]. Isik et al. determined that in $15.4 \%$ of the patients with MFTs, head trauma was also de- 
termined. Of these patients, $6 \%$ had a skull fracture, $5 \%$ had a contusion and $3.6 \%$ had an intracerebral hemorrhage [16].

In a study investigating demographical characteristics of 636 patients, accompanying injuries were determined as abdominal trauma in $6.2 \%$, thorax trauma in $10.3 \%$ and extremity trauma in $6.5 \%$ [28]. In another study, of 246 patients with MFTs, $15.3 \%$ had head trauma, $12.1 \%$ had extremity trauma, $6.8 \%$ had thorax trauma, $2 \%$ had abdominal trauma [1]. In our study, the most common concomitant injury with MFTs was found to be head trauma, followed by extremity trauma. The most common intracranial injury was $\mathrm{SAH}$, the most common intrathoracic injury was pneumo/hemothorax and the most common intraabdominal injury was pelvic fractures. However, any statistically significant correlation could not be obtained between MFT and other system injuries. Since assaults are the most common reason for MFTs in our study, it is not surprising that the most common concomitant injury is head trauma due to proximity of these structures to each other.

In a study from Turkey, it was reported that alcohol intake was determined in $3.1 \%$ of the patients admitted to ER due to trauma. It was also reported that alcohol intake was related to severe injuries following trauma [29]. However, in our study, we could not determine any relationship between alcohol intake and maxillofacial fracture presence. Since alcohol intake is known to be a risk factor for interpersonal violence and motor vehicle accidents, further investigations with definite diagnosis of alcohol or drug intake may be necessary in this field.

In a study, it was reported that while $40.2 \%$ of the patients with MFT were managed in ED, $28.5 \%$ was hospitalized in plastic surgery ward, $10.2 \%$ was hospitalized in neurosurgery ward and $8.5 \%$ was hospitalized in ear-nose-throat ward. In the study, $5.7 \%$ of the patients were reported to be transferred to an advanced center, $97.8 \%$ was discharged with recovery and $2.2 \%$ have lost their lives [1].

In a multi-center study in the US, mortality rate due to severe MFT was reported to be 7\% [30]. In another study by Gerbino et al., 222 patients with MFT over 60 years were investigated and mortality rate was found to be $0.5 \%$ [31].

In our study, compatible with the literature, the most common ward the patients with MFT were transferred was plastic surgery, followed by neurosurgery. Management of MFTs is mainly provided by plastic surgery. As the most common concomitant injury is head trauma, patients are also managed by neyrosurgery. Since intracranial injuries have a higher mortality rate than MFTs, our suggestion is a close neurosurgeon follow-up.

The mortality rate of patients with MFT was found to be $1.6 \%$ in our study. Other system injuries do not only make management of these patients more difficult, but also contributes to high mortality rates. In management of patients with MFT, accompanying injuries must be kept in mind. Major oral cavity bleedings and delayed intubation decision may also result in death. Early interventions and consultations may reduce mortality rate in patients with MFT. Even though we could not determine any relationship between mortality and 
fracture presence, fracture presence should be considered as an indicator of trauma severity.

\section{Conclusion}

In conclusion, MFT is a life-threatening condition both by its own nature and possible accompanying injuries. Timely diagnosis of MFTs and other system injuries and appropriate interventions may be useful in reducing morbidity and mortality following MFTs.

\section{Conflicts of Interest}

The authors declare no conflicts of interest regarding the publication of this paper.

\section{References}

[1] Gönüllü, H., Karadaş, S., Işık, D., Koçak, Ö.F. and Tekin, H. (2012) Bir acil servise başvuran maksillofasiyal travma olgulari: retrospektif bir çalişma. Türk plastik, Rekonstrüktif ve Estetik Cerrahi Dergisi, 19, 121-124.

[2] Gassner, R., Tuli, T., Hächl, O., Rudisch, A. and Ulmer, H. (2003) Cranio-Maxillofacial Trauma: A 10 Year Review of 9543 Cases with 21067 Injuries. Journal of Cranio-Maxillofacial Surgery, 31, 51-61. https://doi.org/10.1016/S1010-5182(02)00168-3

[3] Yüksel, A. and Uslu, S. (2006) Maxillofacial Traumas. Turkiye Klinikleri Journal of Surgical Medical Sciences, 2, 59-67.

[4] Borah, G.L. and Rankin, M.K. (2010) Appearance Is a Function of the Face. Plastic and Reconstructive Surgery, 125, 873-878. https://doi.org/10.1097/PRS.0b013e3181cb613d

[5] Toprak, U. and Gökaslan, Ç.Ö. (2016) Maksillofasiyal, Paranazal ve Orbital Travma (Fasiyal Travmalar). Türk Radyoloji Seminerleri, 4, 229-248. https://doi.org/10.5152/trs.2016.370

[6] Mehta, N., Butala, P. and Bernstein, M.P. (2012) The Imaging of Maxillofacial Trauma and Its Pertinence to Surgical Intervention. Radiologic Clinics of North America, 50, 43-57.

[7] Keleş, B., Öztürk, K., Arbağ, H., Ülkü, Ç.H. and Gezgin, B. (2006) Maksillofasiyal travmalı hastalarda tedavi seçenekleri ve karşılaşılan sorunlar. Ulus Travma Acil Cerrahi Dergisi, 12, 218-222.

[8] Şakrak, T., Köse, A., Karabağlı, Y., Elmas, İ., Tekgöz, A. and Çetin, C. (2010) 232 Maksillofasiyal travmalı hastanın geriye dönük analizi ve kliniğimizde uygulanan tedavi protokolleri. Turkish Journal of Plastic Surgery, 18, 65-69.

[9] Van den Bergh, B., Karagozoglu, K.H., Heymans, M.W. and Forouzanfar, T. (2012) Aetiology and Incidence of Maxillofacial Trauma in Amsterdam: A Retrospective Analysis of 579 Patients. Journal of Cranio-Maxillofacial Surgery, 40, e165-e169. https://doi.org/10.1016/j.jcms.2011.08.006

[10] Mijiti, A., Ling, W., Tuerdi, M., Maimaiti, A., Tuerxun, J., Tao, Y.Z., et al. (2014) Epidemiological Analysis of Maxillofacial Fractures Treated at a University Hospital, Xinjiang, China: A 5-Year Retrospective Study. Journal of Cranio-Maxillofacial Surgery, 42, 227-233. https://doi.org/10.1016/j.jcms.2013.05.005

[11] Cabalag, M.S., Wasiak, J., Andrew, N.E., Tang, J., Kirby, J.C. and Morgan, D.J. 
(2014) Epidemiology and Management of Maxillofacial Fractures in an Australian Trauma Centre. Journal of Plastic, Reconstructive \& Aesthetic Surgery, 67, 183-189. https://doi.org/10.1016/j.bjps.2013.10.022

[12] İrkören, S., Sivrioğlu, N.Ş., Bulut, B., Sonel, A.M. and Ceylan, E. (2011) Üç yll içinde opere denilen 63 mandibula fraktürü olgusunun retrospektif analizi. ADÜ Tip Fakültesi Dergisi, 12, 1-4.

[13] Ortakoğlu, K., Saraçgil, S., Üner, E. and Şener, C. (2001) 37 Hastada oluşan 63 maksillofasiyal fraktürde retrospektif bir çalışma. Cumhuriyet Üniversitesi Dişhekimliği Fakültesi Dergisi, 4, 106-109.

[14] Güven, O., Behçet, E. and Akif, Ö. (1985) Güneydoğu Anadolu Bölgesinde Görülen Çene Kırıkları Üzerine Klinik Bir Araştırma. Acta Odontologica Turcica, 2, 65.

[15] Demir, Z., Öktem, F., Velidedeoğlu, H. and Çelebioğlu, S. (2008) Maksillofasiyal kırığı olan 121 olgunun değerlendirilmesi ve literatürle karşılaştırılması. KBB-Forum, 7, 85-90.

[16] Işik, D., Gönüllü, H., Karadaş, S., Koçak, Ö.F., Keskin, S., Garca, M.F., et al. (2012) Presence of Accompanying Head Injury in Patients with Maxillofacial Trauma. Turkish Journal of Trauma \& Emergency Surgery, 18, 200-206. https://doi.org/10.5505/tjtes.2012.01047

[17] Bataineh, A.B. (1998) Etiology and Incidence of Maxillofacial Fractures in the North of Jordan. Oral Surgery, Oral Medicine, Oral Pathology, Oral Radiology, 86, 31-35. https://doi.org/10.1016/S1079-2104(98)90146-9

[18] Adi, M., Ogden, G. and Chisholm, D. (1990) An Analysis of Mandibular Fractures in Dundee, Scotland (1977 to 1985). British Journal of Oral and Maxillofacial Surgery, 28, 194-199. https://doi.org/10.1016/0266-4356(90)90088-3

[19] Haug, R.H., Prather, J. and Indresano, A.T. (1990) An Epidemiologic Survey of Facial Fractures and Concomitant Injuries. Journal of Oral and Maxillofacial Surgery, 48, 926-932. https://doi.org/10.1016/0278-2391(90)90004-L

[20] Sofferman, R.A., Danielson, P.A., Quatela, V. and Reed, R.R. (1983) Retrospective Analysis of Surgically Treated Le Fort Fractures: Is Suspension Necessary? Archives of Otolaryngology, 109, 446-448. https://doi.org/10.1001/archotol.1983.00800210022004

[21] Rix, L., Stevenson, A. and Punnia-Moorthy, A. (1991) An Analysis of 80 Cases of Mandibular Fractures Treated with Miniplate Osteosynthesis. International Journal of Oral and Maxillofacial Surgery, 20, 337-341. https://doi.org/10.1016/S0901-5027(05)80261-9

[22] Sojat, A.J., Meisami, T., Sàndor, G.K. and Clokie, C.M. (2001) Epidemiology of Mandibular Fractures Treated at the Toronto General Hospital: A Review of 246 Cases. Journal-Canadian Dental Association, 67, 640-645.

[23] Zargar, M., Khaji, A., Karbakhsh, M. and Zarei, M. (2004) Epidemiology Study of Facial Injuries during a 13 Month of Trauma Registry in Tehran. Indian Journal of Medical Sciences, 58, 109.

[24] Arslan, E.D., Solakoglu, A.G., Komut, E., Kavalci, C., Yilmaz, F., Karakilic, E., et al. (2014) Assessment of Maxillofacial Trauma in Emergency Department. World Journal of Emergency Surgery, 9, 13. https://doi.org/10.1186/1749-7922-9-13

[25] Yıldırım, N., Sayın, B., Durakoğlugil, T., Soydinç, P. and Dede, D. (2010) Maksillofasiyal Travmalarda İntraorbital Yabancı Cisimler. Turkish Journal of Emergency Medicine, 10, 71-76.

[26] Mulligan, R.P. and Mahabir, R.C. (2010) The Prevalence of Cervical Spine Injury, 
Head Injury, or Both with Isolated and Multiple Craniomaxillofacial Fractures. Plastic and Reconstructive Surgery, 126, 1647-1651. https://doi.org/10.1097/PRS.0b013e3181ef90e4

[27] Roccia, F., Bianchi, F., Zavattero, E., Tanteri, G. and Ramieri, G. (2010) Characteristics of Maxillofacial Trauma in Females: A Retrospective Analysis of 367 Patients. Journal of Cranio-Maxillofacial Surgery, 38, 314-319. https://doi.org/10.1016/j.jcms.2009.10.002

[28] Akoğlu, H., Denizbaşı, A., Ünlüer, E., Güneysel, Ö. and Onur, Ö. (2005) Marmara üniversİtesİ hastanesi acil servisine başvuran travma hastalarinin demografik özellikleri. Marmara Medical Journal, 18, 113-122.

[29] Ceylan, S., Açikel, C.H., Dündaröz, R., Yaşar, M., Güleç, M. and Özişik, T. (2002) Bir Eğitim Hastanesi Acil ServisineTravma Nedeniyle Başvuran Hastaların Sıklığının Ve Travma Özelliklerinin Saptanması. Turkiye Klinikleri Journal of Medical Sciences, 22, 156-161.

[30] Cogbill, T.H., Cothren, C.C., Ahearn, M.K., Cullinane, D.C., Kaups, K.L., Scalea, T.M., et al. (2008) Management of Maxillofacial Injuries with Severe Oronasal Hemorrhage: A Multicenter Perspective. The Journal of Trauma: Injury, Infection, and Critical Care, 65, 994-999. https://doi.org/10.1097/TA.0b013e318184ce12

[31] Gerbino, G., Roccia, F., De Gioanni, P.P. and Berrone, S. (1999) Maxillofacial Trauma in the Elderly. Journal of Oral and Maxillofacial Surgery, 57, 777-782. https://doi.org/10.1016/S0278-2391(99)90812-1 